\author{
M.B. Rebezov ${ }^{1} *$, Ye.B. Nikitin ${ }^{2}$, M.V. Temerbayeva ${ }^{2}$, T.I. Uryumtseva ${ }^{2}$ \\ ${ }^{1}$ Federal State Budgetary Scientific Institution \\ «Federal Scientific Center for Food Systems named after V.M. Gorbatov», Russia \\ ${ }^{2}$ Innovative University of Eurasia, Kazakhstan \\ *(e-mail: rebezov@yandex.ru)
}

\title{
Current state and prospects of fortified food production in Russia and Kazakhstan
}

\begin{abstract}
Main problem: The article examines promising directions in the production of fortified food products in Kazakhstan and Russia. The authors carried out an analytical review of the current state of production of fortified bakery products on the territory of the Russian Federation and the Republic of Kazakhstan. Anemia has been described as one of the most common consequences of micronutrient deficiencies. The problems associated with anemia lead to serious complications for the health and well-being of people. Lack of folic acid and vitamins in the diet is the cause of cardiovascular disease, maternal and child mortality.

Purpose: The article considers the problem of significant deviations in nutrition of almost all groups of the population of Russia and Kazakhstan, regardless of lifestyle, habits or income level, which have an extremely negative effect on the health of the nation: the average life expectancy decreases, the productivity of the working-age population and resistance to diseases decrease.

Methods: Based on the studied domestic and foreign technical literature, patent information, an analytical review of the current state and prospects of the production of fortified food products in the Russian Federation and the Republic of Kazakhstan was carried out.

Results and their significance: The authors have shown that food fortification is the practice of purposefully increasing the content of vitamins and microelements in food to improve the nutritional quality of food and have a positive effect on human health. The authors considered the question of how the problem of micronutrient deficiency, including iron, is currently being effectively solved in many countries by enriching food products of mass consumption with vitamins and minerals.
\end{abstract}

Key words: fortification, trace elements, vitamins, premix, folic acid, bakery products, iron deficiency anemia.

\section{Introduction}

In Kazakhstan, as in the rest of the world, the goals of the state policy in the field of healthy nutrition are to preserve and strengthen the health of the nation, as well as prevent diseases associated with malnutrition of all segments of the population. In the scientific field, fundamental, complex and interdisciplinary research is carried out in the field of nutritional science and related fields, scientific projects, applied research and development work are carried out to create the latest technologies for the production, processing, storage and transportation of food raw materials and food products.

One of the common problems that threaten human health is a lack of vitamins and minerals in the diet, including iron and folic acid. One of the most common consequences of micronutrient deficiencies is anemia. The problems associated with anemia lead to serious complications for the health and well-being of people. Lack of folic acid and vitamins in the diet is the cause of cardiovascular disease, maternal and child mortality. A 2019 national study by the Kazakh Academy of Nutrition found that anemia is widespread among women of reproductive age $(39 \%)$ and children under $5(35 \%)$. The solution to the problem of vitamin and mineral deficiency in many countries was the fortification-enrichment of food products of mass and regular consumption with the missing components. Today, most of the food, as a result of technological processing, loses its useful properties. The best way to restore them is enrichment [1].

Flour fortification is recognized by international organizations (WHO, UNICEF, International Food Fortification Initiative) as a widely approved, highly effective, easily implemented and inexpensive method of preventing and controlling iron deficiency anemia, vitamin and micronutrient deficiencies. According to the WHO, no more than $15 \%$ of health interventions can be carried out within the health system. $70 \%$ of the health of the nation depends on the way of life, first of all, on a balanced diet. Anemia, lack of folic acid and vitamins in the diet are the cause of cardiovascular diseases, maternal and child mortality, disability, which leads to a decrease in Kazakhstan's ranking in the global competitiveness index. According to the Kazakh Academy of Nutrition, 6,5 million people in Kazakhstan suffer from anemia, which is one of the reasons for the high rate of maternal and child mortality.

In Kazakhstan, up to 90,000 people die a year from anemia, which occurs in $45 \%$ of women, $47 \%$ of children and $26 \%$ of men in Kazakhstan. Moreover, it was said that up to 1000 young children die each year or are at risk of dying after birth due to severe anemia in their mothers, and up to 22,6\% of mothers die during or 
after childbirth due to severe anemia. They also told reporters that every second child in Kazakhstan at the age of 6 months to 2 years has a lag in growth and development. Also, $5 \%$ of children have reduced school performance and about 2,000,000 children will not be able to realize their abilities after they reach 20 years of age. And due to the deficiency of folic acid, up to $80 \%$ of women of reproductive age and children are susceptible to the development of atherosclerosis, heart attacks, strokes, as well as a number of oncological diseases [2].

At the meeting, the National Commission on Women Affairs and Family and Demographic Policy under the President of the Republic of Kazakhstan raised the issue of fortification (fortification with vitamins) of food products. Due to the lack of fortification in food, $40 \%$ of Kazakhstanis suffer from a serious disease - iron deficiency anemia, the meeting participants reported with reference to the Kazakh Academy of Nutrition. Kazakhstanis daily consume flour in the form of bakery and pasta, it is a staple product. The consumption of fortified foods affects human health. The most important element that foods should be enriched with is iron.

Mass surveys of the population, regularly conducted in Kazakhstan, indicate significant deviations in the nutrition of almost all groups of the population, regardless of lifestyle, habits or income level. This fact has an extremely negative effect on the health of the nation: the average life expectancy is reduced, the productivity of the working-age population and resistance to diseases decrease. One of the most optimal ways to solve the problem of micronutrient deficiency is: food fortification.

Food fortification is the practice of purposefully increasing the vitamin and trace element content of food in order to improve the nutritional quality of food and have a positive effect on human health. About $30 \%$ of people around the world lack vitamins and trace elements in food. Therefore, in many countries at the state level there are special programs - more than 75 countries on the mandatory fortification of flour with microelements. Fortification has absolutely no effect on the organoleptic and other properties of flour and does not cause side effects. Flour is subject to fortification only of the highest and first grade, during the production of which the grain is cleaned from the shell containing the maximum amount of micronutrients (vitamins). Fortified flour has a shelf life of six months.

Baking wheat flour of the highest and first grades produced for sale in the Republic of Kazakhstan is subject to mandatory enrichment (fortification) with iron-containing vitamins, minerals, amino acids, fatty acids and other substances. According to medical indications in 2019, 12,300 residents of Pavlodar region have iron deficiency anemia - such data are provided by the Department of Public Health with reference to the Republican Center of Electronic Health. Slightly less than half of this figure is children and adolescents. In general, the incidence rate in the country was 1812,6 cases per 100 thousand of the population, and in Pavlodar region 708,2 per 100 thousand. Therefore, the Pavlodar medical community calls on millers to more actively enrich flour with special impurities.

The problem of providing the population with fortified food products in order to eliminate iodine deficiency, reduce iron deficiency anemia and folate deficiency is one of the most urgent in Kazakhstan. The deficiency of these micronutrients has a serious impact on the learning ability and performance of large groups of the country's population, creates tension in the health and education systems, reduces labor productivity and can increase poverty. For the prevention of diseases and improving the quality of life of the population of the Republic of Kazakhstan, the development of fortified bakery products is promising. The need for flour fortification is spelled out in the legislation of Kazakhstan. Moreover, Article 160 of the Code of the Republic of Kazakhstan «On the health of the people and the health care system» approved the mandatory fortification with iron-containing vitamins, minerals and other substances of the highest and first grade wheat flour sold in the country. The same is stipulated by the Rules for fortification (fortification) of food products subject to sanitary and epidemiological supervision, which are approved by order and. about. Minister of National Economy of the Republic of Kazakhstan dated February 24, 2015. Thus, the creation of fortified food products is a relevant direction.

\section{Materials and methods}

On the basis of the studied domestic and foreign technical literature, patent information, an analytical review of the current state and prospects of the production of fortified food products in the Russian Federation and the Republic of Kazakhstan was carried out.

\section{Results}

Today, there are 322 flour mills in Kazakhstan, of which 252 are large-scale industries, of which 90 are fortification (fortification) with vitamins and microelements. Flour is the most affordable product for all segments of the population. Before milling, whole wheat grains contain a significant amount of protein, carbohydrates and fiber, many vitamins and minerals. And after this process, only pure white endosperm remains. So, the final product is less nutritious. And only leads to higher quality and nutritional value of products.

Fortification has absolutely no effect on the organoleptic and other properties of flour and does not cause side effects. Flour is to be fortified only of the highest and first grade, during the production of which the grain is cleaned from the shell containing the maximum amount of micronutrients (vitamins). Fortified flour has a shelf life of six months.

Baking wheat flour of the highest and first grades produced for sale in the Republic of Kazakhstan is subject to mandatory enrichment (fortification) with iron-containing vitamins, minerals, amino acids, fatty acids 
and other substances. Data on the fortification carried out will necessarily be reflected by the manufacturer on the labeling of goods in accordance with the requirements of Technical Regulations of the Customs Union 022 / 2011 «Food products in terms of their labeling».

Such products are appearing in an increasing range on the Kazakhstani market, and are represented mainly by consumer products (flour, milk and dairy products). The content of vitamins added to them is calculated in such a way as to cover 30-50 \% of the body's daily need for these substances.

Wheat flour of the highest and first grades, sold in the territory of the Republic of Kazakhstan, is subject to mandatory fortification. The reasons:

1. Flour is consumed by almost the entire population of the country;

2. There is a very high probability of state control of the price of flour, which makes it affordable for low-income groups of the population;

3. The bulk of flour is produced in large mills and can be supplied centrally to all regions of the country;

4. It is quite easy to determine the exact amount of micronutrient intake (on average, adults consume 250-270 g of flour per day);

5. When grinding grain, 70-95\% of micronutrients are lost with bran.

Fortified Kazakh flour has the SAPALY AZYK logo on the label or bag. Flour is enriched with a complex of vitamins and microelements specially developed for our country by the Kazakh Academy of Nutrition. In addition to iron, the premix contains folic acid, zinc and B vitamins. Iron and folic acid will help protect us and our loved ones from anemia, maternal mortality, congenital malformations, heart attacks and strokes.

Also in Kazakhstan for many years there is a special complex of vitamins, which is called a premix, which includes $-\mathrm{B}_{1}, \mathrm{~B}_{2}$, iron, zinc, folic and niacin. It was specially developed for flour fortification. About 150 grams of premix is added to a ton of flour, because with the transition to fine grinding for the production of the first and highest grade flour, many vitamins began to be lost during the technological process. Thus, the proposed combination is a kind of replenishment of the lost valuable qualities of the product.

The cost of fortification of flour per capita per year is only 40 tenge. It is assumed that the effect of the use of fortified flour will come in 1-2 years, when the hemoglobin level in the blood of fans of fortified bakery products will return to normal. Kazakhstan is almost ready to launch such a product. More than 20 large flourgrinding enterprises of the country are already equipped with the necessary equipment and have positive experience. Moreover, for several years now this flour has been produced in the country and more than 500,000 tons of it have already been sold [3].

Currently, in many countries, the problem of micronutrient deficiency, including iron, is being effectively solved by enriching food products of mass consumption with vitamins and minerals (flour, bakery, pasta, confectionery, dairy products, juice drinks).

Scientists of the Pacific State Economic University and the Pacific Institute of Bioorganic Chemistry (Vladivostok) E.S. Smertina, T.K. Kalenik, L.N. Fedyanina, N.M. Shevchenko, Zvyagintseva developed bakery products for therapeutic and prophylactic purposes from brown algae. The possibility and expediency of enrichment of bakery products with dietary supplements to food fucol, developed on the basis of brown alga $\mathrm{F}$. Evanescens [4].

Russian scientists of the southwestern University AG Belyaev, AE Kovaleva, EA Pyanikova, AG Kaluzhskikh studied the macroelement composition of bakery products enriched with narrow-leaved fireweed products using scanning electron microscopy [5].

N.L. Naumova, A.E. Vashetskaya, V.F. Druzhkova (Chelyabinsk State University), in the course of comprehensive studies to study the effect of the food additive «Seleksen» and vitamin premixes 986 and H30305 on the quality of bakery products, established regulated quality indicators for fortified bakery products, developed and approved technical documentation for production: selenium "enriched with vitamins B3, B12, E, PP, H, B1, B2, BC, B6, and bun «Selena» enriched with vitamins A, B $, \mathrm{B}_{12}, \mathrm{E}, \mathrm{PP}, \mathrm{H}, \mathrm{B}_{1}, \mathrm{~B}_{2}, \mathrm{~B}_{6}$ [6].

Scientists of the South Ural State University (Chelyabinsk) A.V. Paimulina, N.V. Androsov, N.V. Naumenko studied and analyzed the prospects for the use of fortifying additives in the technology of bakery products [7].

Scientists from the Federal State Budgetary Educational Institution of Higher Professional Education «State University - Educational Research and Production Complex» (Orel c.) and the Federal State Budgetary Educational Institution of Higher Professional Education «North Caucasus Federal University» (Pyatigorsk c.) jointly conducted research and presented the results of the effectiveness of the use of fortified bakery products in the diet of schoolchildren 7-18 years, and also developed recipes and technology for fortified bakery products [8].

Employees of the Department of Metrology, Standardization and Certification of Orenburg State University are conducting research to expand the range of indicators of food quality, to develop formulations and technologies for enriching them with organic compounds of scarce bioelements. At the Orenburg State University, scientists L. N. Tretyak. And D.I. Yavkina. They have developed additional requirements for the quality and safety of food products fortified with additives [9].

Russian scientists at the Kemerovo Technological Institute of the Food Industry are conducting research on the technology of using secondary resources of berry raw materials in the technology of confectionery and 
bakery products. Thus, scientists I.A. Bakin, A.S. Mustafina, E.A. Vechtomova, A. Yu. Kolbin in their studies proved that the extraction of biologically active substances from the berry culture black currant (Ribes nigrum L.), with the right processing methods, allows you to obtain butter biscuits and bakery products with a high composition of active substances using secondary plant materials [10].

At the Department of Applied Biotechnology of the Faculty of Food Technologies of the South Ural State University, scientists M.B. Rebezov, N.L. Naumova et al. Carried out a number of research works on enrichment of bakery products with essential micronutrients, the deficit of which is due to the biogeochemical conditions of the Ural region (Russia, Chelyabinsk c.) [11].

V.L. Kudryashov (All-Russian Research Institute of Food Biotechnology, Federal State Budgetary Institution of Science «Federal Research Center for Nutrition and Biotechnology») created the concept of creating a production of supplements for enriching bakery products with vitamins in schools and hospitals within the framework of the program «Fundamentals of State Policy in the Field of Healthy Nutrition until 2020» and has developed a vitamin and mineral complex «Profitin», which corresponds to Russian state standard No. 57106-2016 «Products for dietary, medical and preventive dietary nutrition. Vitamin and mineral complexes in nutritional care». «Protifin» is intended for enrichment of bakery products, and the biologically active substances contained in it provide from 50 to $100 \%$ of the body's daily need for vitamins and minerals [12].

In LLP «Kazakh Academy of Nutrition» of the Kazakh National Medical University named after S.D. Asfendiyarov, Almaty, scientists G.A. Tarakova, M.A. Bakirova, S.A. Bykybaeva, G.N. Serzhanov, R.B. Yergeshbaeva conducted research and obtained results on the fortification of flour of the highest and first grades with a vitamin and mineral complex in the Kyzylorda region in the target groups of the population in terms of preventing deficiency of iron, zinc and folic acid [13].

Joint research was carried out by Kazakh and Russian scientists S. K. Mizanbekova (Non-commercial joint-stock company «Kazakh National Agrarian University», Almaty), as well as I.P. Bogomolova, N.M. Shatokhina, A.V. Bogomolov (Federal State Budgetary Educational Institution of Higher Education «Voronezh State University of Engineering Technologies») developed innovative tools in resource efficiency and quality management as a tool for the balanced development of flour mills. The developed management decisions are aimed at increasing the competitiveness of flour mills that operate using flour fortification and fortification methods in Kazakhstan, Altai Territory, Kemerovo, Tomsk, Ryazan and Leningrad regions, as well as Bashkiria and Tatarstan [14].

With the support of international organizations in Kazakhstan, in 2003, a program of fortification of first and highest grade wheat flour began with six micronutrients: iron, zinc and 4 vitamins $\left(\mathrm{B}_{1}, \mathrm{~B}_{2}\right.$, folic and niacin). Premix, a mixture for enriching flour with these six micronutrients, was developed by the Kazakh Academy of Nutrition.

The advantages of this strategy are its low cost and the ability to reach the entire population. Wheat flour is an optimal product for fortification for the following reasons:

- is a mass food product consumed in large quantities by all age and social groups of the population;

- small daily dosages of vitamins and minerals are used to ensure their optimal absorption by the body;

- safety, since it is impossible to consume the product in an amount dangerous to health;

- added vitamins and microelements are natural components of grain, most of which are lost during the grinding process, i.e. new elements are not introduced;

- rationality and low cost, which determine the availability for the most needy segments of the population;

- simple adaptation to the existing technological process (other food products do not have such advantages);

- no negative effects that could affect the appearance, baking quality or shelf life.

In 2012, at the Almaty Technological University, scientists A.N. Zhakataeva, R.U. Uazhanov conducted a study of bread with the addition of A. Cruentus Amaranth flour for sanitary and microbiological condition [15].

In 2013, at the Kazakh Research Institute of Processing and Food Industry, scientists Batyrbaeva, S.T. Zhienbaeva, Zh.S. Alimkulovs proposed a solution to the problem of enrichment of bakery flour with biologically active substances [16].

At present, scientists of the Almaty Technological University are conducting research on the use of grain additives in bread production, innovative technologies have been developed for the production of bread in an accelerated way with and without the use of sourdough and yeast [17].

Discussion. According to data from the Kazakh Academy of Nutrition, 92,8\% of the country's population has a daily diet that includes the consumption of bread. Wheat and rye, the most common grains, are themselves good sources of vitamins $\mathrm{B}_{1}, \mathrm{~B}_{2}, \mathrm{~B}_{6}$, E, niacin, as well as iron and zinc [18].

However, the processing of grain for flour, baking and other types of technological processing in the preparation of bakery, flour confectionery and grain products are accompanied by significant losses of vitamins and minerals. Since most of the micronutrients are concentrated in the outer shell and in the germ of the grain, the main losses occur during the flour grinding process. Most of the vitamins and minerals are lost in the production of white flour. Thus, when preparing high-grade flour, together with the bran, up to 75-90\% of the micronutrients contained in the original grain are lost. The iron content decreases 4 times, the amount of such 
trace elements necessary for the full assimilation of iron and the synthesis of hemoglobin as copper (3 times), zinc (35 times), magnesium (3,7 times) and manganese (3 times , 8 times).

Highly refined flour (premium grade) contains 9 times less vitamin $\mathrm{B}_{1}, 2$ times less vitamin $\mathrm{B}_{2}$, 6,8 times less vitamin PP (niacin) than wallpaper flour (it turns out when wheat is milled, but not sifted into As a result, such flour retains all the nutrients contained in the whole grain of wheat).

Fortification of wheat flour with iron compounds is the best long-term strategy to improve iron consumption in Kazakhstan's population. Fortification of wheat flour with iron in combination with other trace elements and vitamins has a number of obvious advantages over other strategies to prevent IDA and micronutrient deficiencies. The flour fortified with the premix satisfies 30-50\% of the average daily requirement for vitamins and microelements at the usual level of flour consumption. The process of fortification of flour with iron and vitamin-mineral complexes is carried out directly at flour mills with the help of special installations, which allow achieving a uniform distribution of the introduced premix in specified dosages.

When choosing the form of iron and the composition of the vitamin-mineral complex (premix), the following factors are taken into account:

- compatibility of the ingredients included in the premix;

- the complex should not change the organoleptic properties of wheat flour;

- the fortification should be as stable as possible during long-term storage;

- the fortification should not lead to a significant increase in the price of fortified flour.

With the achievement of mass and regular use of fortified flour and products from it by all segments of the population, it is possible to significantly reduce the prevalence of anemia and improve people's health.

In Pavlodar region, 21 grain processing enterprises are under the control of the department of sanitary and epidemiological supervision and territorial divisions, including 18 flour mills, which produced 16,176 tons of flour of the first and highest grades in 2019. Flour fortification was carried out at 7 enterprises, with dispensers installed at 2, and the remaining 5 fortification by accompanying each bag with packaging of a premix. In 2019, 16 thousand tons of Pavlodar flour, only 254 tons were fortified, which is only 1,5\%. Doctors believe that this is too little, because even educational and health care facilities are provided with such flour only by $27 \%$ of the need.

In 2019, a round table was held in the Maysky District Department of Public Health on the topic «On the state of providing the population of the Maysky District with fortified (fortified) flour». The heads of rural districts were invited to the meeting: Baskol, Koktobe, Maysk where food industry facilities operate and bread is sold. Individual entrepreneurs and interested departments also took part. The issues of food safety, rules of fortification (fortification) of food products subject to sanitary and epidemiological supervision were considered. Fortification of food products of mass demand, primarily flour, iron preparations and much more. The sanitary requirements for the maintenance of the food industry were explained and the problems of individual entrepreneurs with food industry facilities were discussed. Prevention of iron deficiency anemia is the use of mass-market products, primarily bread and bakery products, iodized salt, iodized yeast, mineral water, milk containing minerals, iron, iodine. According to medical indications in 2019, 12,300 residents of Pavlodar region have iron deficiency anemia - such data are provided by the Department of Public Health with reference to the Republican Center of Electronic Health. Slightly less than half of this figure is children and adolescents. In general, the incidence rate in the country was 1812,6 cases per 100 thousand of the population, and in Pavlodar region $-708,2$ per 100 thousand. The local medical community calls on millers to more actively enrich flour with special impurities. According to technologists of Pavlodar region, fortified flour in bakery products will help to overcome anemia and prevent diseases of the digestive system.

\section{Conclusion}

Thus, having studied the scientific research of domestic and foreign scientists on the development of fortified (fortified) bakery products, we can conclude that one of the rational ways to solve this problem in Russia and Kazakhstan is to expand the range and develop technologies for fortified products of everyday and mass demand for all groups of population.

\section{THE LIST OF SOURCES}

1 Аргументы в поддержку обязательной фортификации муки в Казахстане. - [Электронный ресурс]. Режим доступа: http://4-i-5.ru/text-3/page-11-ref-23077.php.

2 Медиа портал «Караван». - [Электронный ресурс]. - Режим доступа: https://www.caravan.kz/articles/obogashhenie-i-muki-370966/.

3 Евич О. Фортификация муки - что нужно об этом знать? - [Электронный ресурс]. - Режим доступа: https://44030.kz/fortifikaciya-muki-chto-nuzhno-ob-etom-znat/.

4 Смертина Е.С. Хлебобулочные изделия с добавкой из бурых водорослей / Е.С. Смертина, Т.К. Каленик // Пищевая промышленность. - 2012. - № 12. - С. 66-67.

5 Беляев А. Е. Изучение макроэлементного состава хлебобулочных изделий, обогащенных продуктами кипрея узколистного, с использованием растровой электронной микроскопии / А.Е. Беляев, А.Е. Ковалева, Э.А. Пьяникова, А.Г. Калужских // Технологии пищевой и перерабатывающей промышленности АПК-продукты здорового питания. - 2019. - № 3. - С. 99-104. 
6 Наумова Н.Л. О развитии производства обогащенных хлебобулочных изделий в условиях Челябинской области / Н.Л. Наумова, А.Е. Вашецкая, В.Ф. Дружкова // Вестник Алтайского государственного аграрного университета. - 2014. - № 11(121). - С. 186-192.

7 Паймулина А.В. Перспективы использования обогащающих добавок в технологии хлебобулочных изделий / А.В. Паймулина, Н.В. Андросова, Н.В. Науменко // Вестник ЮУрГУ. Серия «Пищевые и биотехнологии» - 2016. - Т.4, № 4. - С. 95-104.

8 Корячкина С.Я. Эффективность применения обогащенных хлебобулочных изделий в питании детей / С. Я. Корячкина, О.Л. Ладнова, С.Л. Люблинский, Е.Н. Холодова // Вопросы питания. - 2015. - Т. 84, № 3. - C. 87-94.

9 Третьяк Л.Н. Дополнительные требования к качеству и безопасности пищевых продуктов, обогащенных добавками / Л. Н. Третьяк, Д. И. Явкина // Пищевая промышленность. - 2018. - № 5. С. $18-21$.

10 Бакин И.А. Использование вторичных ресурсов ягодного сырья в технологии кондитерских и хлебобулочных изделий / И.А. Бакин, А.С. Мустафина, Е.А. Вечтомова, А.Ю. Колбина // Техника и технология пищевых производств. - 2017. - Т. 45, № 2. - С. 5-12.

11 Ребезов М.Б. О возможности обогащения хлебобулочных изделий функциональными ингредиентами / М.Б. Ребезов, Н.Л. Наумова, М.Ю. Кофанова, Н.В. Выдрина, А.В. Демидов // Техника и технология пищевых производств. - 2012. - № 1. - С. 1-4.

12 Ребезов М.Б. Изучение отношения потребителей к обогащенным продуктам питания / М.Б. Ребезов, Н.Л. Наумова, Г.К. Альхамова, А.А. Лукин, М.Ф. Хайруллин // Пищевая промышленность. - 2011. - № 5. - C. 13-15.

13 Таракова Г.А. Результаты проведения фортификации муки высшего и первого сортов в Кызылординской области / Г.А. Таракова, М.А. Бакирова, С.А. Быкыбаева, Г.Н. Сержанова, Р.Б. Ергешбаева // Вестник КазНМУ. -2016. - № 3. - С. 683-686.

14 Мизанбекова С.К. Инновационные инструменты в ресурсоэффективности и управлении качеством, как инструмент сбалансированного развития мукомольных предприятий / С.К. Мизанбекова, И.П. Богомолова, Н.М. Шатохина, А.В. Богомолов // Техника и технология пищевых производств. 2018. - Т. 48, № 3. - С. $152-160$.

15 Жакатаева А.Н. Санитарное и микробиологическое исследование хлеба с добавленим муки амаранта A. Cruentus / А.Н. Жакатаева, Р.У. Уажанова // Вестник Алматинского технологического университета. 2012. - № 6. - С. 63-67.

16 Батырбаева Н.Б. Анализ проблемы обогащения хлебопекарной муки биологически активными веществами / Н.Б. Батырбаева, С.Т. Жиенбаева, Ж.С. Алимкулов // Вестник Алматинского технологического университета. - 2013. - № 5. - С. 5-9.

17 Изтаев А.И. Инновационные технологии производства хлеба ускоренным способом с и без использования закваски и дрожжей / А.И. Изтаев, Ш.А. Турсунбаева, М.Г. Магомедов // Вестник Алматинского технологического университета. - 2019. - № 1. - С. 5-11.

18 Шаншарова Д.А. Использование зерновых добавок в производстве хлеба / Д.А. Шаншарова, Ж.К. Нургожина, Л.Ж. Алашбаева, Г.М. Кайчибекова // Вестник Алматинского технологического университета. - 2019. - № 3. - С. 5-8.

\section{REFERENCES}

1 Argumenty v podderzhku obyazatel'noy fortifikatsii muki v Kazakhstane [Arguments in support of mandatory flour fortification in Kazakhstan]. 4-i-5.ru. Retrieved from http://4-i-5.ru/text-3/page-11-ref-23077.php [in Russian].

2 Media portal «Karavan» [Media portal «Caravan»]. caravan.kz. Retrieved from https://www.caravan.kz/articles/obogashhenie-i-muki-370966/ [in Russian].

3 Yevich, O. (2017). Fortifikatsiya muki- chto nuzhno ob etom znat'? [Flour fortification - what you need to know about it?]. 44030.kz. Retrieved from https:/44030.kz/fortifikaciya-muki-chto-nuzhno-ob-etom-znat/ [in Russian].

4 Smertina, Ye.S., \& Kalenik, T.K. (2012). Khlebobulochnyye izdeliya s dobavkoy iz burykh vodorosley [Flour fortification - what you need to know about it?]. Pishchevaya promyshlennost' - Food industry, 12, 66-67 [in Russian].

5 Belyayev, A.Ye., Kovaleva, A.Ye., P'yanikova, E.A., \& Kaluzhskikh A.G. (2019). Izucheniye makroelementnogo sostava khlebobulochnykh izdeliy, obogashchennykh produktami kipreya uzkolistnogo, $\mathrm{s}$ ispol'zovaniyem rastrovoy elektronnoy mikroskopii [Study of the macronutrient composition of bakery products enriched with products of narrow-leaved fireweed using scanning electron microscopy]. Tekhnologii pishchevoy i pererabatyvayushchey promyshlennosti APK-produkty zdorovogo pitaniya - Technologies of food and processing industry Agroindustrial complex - healthy food products, 3, 99-104 [in Russian].

6 Naumova, N.L., Vashetskaya, A.Ye., \& Druzhkova, V.F. (2014). O razvitii proizvodstva obogashchennykh khlebobulochnykh izdeliy v usloviyakh Chelyabinskoy oblasti [About the development of production of fortified 
bakery products in the conditions of the Chelyabinsk region]. Vestnik Altayskogo gosudarstvennogo agrarnogo universiteta - Bulletin of the Altai State Agrarian University, 11, 186-192 [in Russian].

7 Paymulina, A.V., Androsova, N.V., \& Naumenko, N.V. (2016). Perspektivy ispol'zovaniya obogashchayushchikh dobavok $\mathrm{v}$ tekhnologii khlebobulochnykh izdeliy [Prospects for the use of enriching additives in the technology of bakery products]. Vestnik YUUrGU. Seriya «Pishchevyye i biotekhnologii»Bulletin of the South Ural State University. Series «Food and Biotechnology», 4,4, 95-104 [in Russian].

8 Koryachkina, S. YA., Ladnova, O.L., Lyublinskiy, S.L., \& Kholodova, Ye.N. (2015). Effektivnost' primeneniya obogashchennykh khlebobulochnykh izdeliy $\mathrm{v}$ pitanii detey [Efficiency of the use of enriched bakery products in children's nutrition]. Voprosy pitaniya - Nutrition issues, 84,3, 87-94 [in Russian].

9 Tret'yak, L. N.., \& Yavkina, D. I. (2018). Dopolnitel'nyye trebovaniya k kachestvu i bezopasnosti pishchevykh produktov, obogashchennykh dobavkami [Additional requirements for the quality and safety of food products enriched with additives]. Pishchevaya promyshlennost' - Food industry, 5, 18-21 [in Russian].

10 Bakin, I.A., Mustafina, A.S., Vechtomova, Ye.A., \& Kolbina A.YU. (2017). Ispol'zovaniye vtorichnykh resursov yagodnogo syr'ya $\mathrm{v}$ tekhnologii konditerskikh i khlebobulochnykh izdeliy [The use of secondary resources of berry raw materials in the technology of confectionery and bakery products]. Tekhnika $\mathrm{i}$ tekhnologiya pishchevykh proizvodstv - Technics and technology of food production, 45, 2, 5-12 [in Russian].

11 Rebezov, M.B., Naumova, N.L., Kofanova, M.YU., Vydrina, N.V., \& Demidov, A.V. (2012). O vozmozhnosti obogashcheniya khlebobulochnykh izdeliy funktsional'nymi ingrediyentami [About the possibility of enrichment of bakery products with functional ingredients]. Tekhnika i tekhnologiya pishchevykh proizvodstv - Technique and technology of food production, 1, 1-4 [in Russian].

12 Rebezov, M.B., Naumova, N.L., Al'khamova, G.K., Lukin, A.A., \& Khayrullin, M.F. (2011). Izucheniye otnosheniya potrebiteley k obogashchennym produktam pitaniya [Study of consumer attitudes towards enriched food products]. Pishchevaya promyshlennost' - Food industry, 5, 13-15 [in Russian].

13 Tarakova, G.A., Bakirova, M.A., Bykybayeva, S.A., Serzhanova, G.N., \& Yergeshbayeva, R.B. (2016). Rezul'taty provedeniya fortifikatsii muki vysshego i pervogo sortov v Kyzylordinskoy oblasti [Results of fortification of flour of the highest and first grades in the Kyzylorda region]. Vestnik Kazakhskogo Natsional'nogo meditsinskogo universiteta - Bulletin of the Kazakh National Medical University, 3, 683-686 [in Russian].

14 Mizanbekova, S.K., Bogomolova, I.P., Shatokhina, N.M., \& Bogomolov, A.V. (2018). Innovatsionnyye instrumenty $\mathrm{V}$ resursoeffektivnosti i upravlenii kachestvom, kak instrument sbalansirovannogo razvitiya mukomol'nykh predpriyatiy [Innovative instruments in resource efficiency and quality management as a tool for the balanced development of flour-grinding enterprises]. Tekhnika i tekhnologiya pishchevykh proizvodstv Technics and technology of food production, 48,3, 152-160 [in Russian].

15 Zhakatayeva, A.N., \& Uazhanova, R.U. (2012). Sanitarnoye i mikrobiologicheskoye issledovaniye khleba s dobavlenim muki amaranta A. Cruentus [Sanitary and microbiological research of bread with the addition of amaranth flour A. Cruentus]. Vestnik Almatinskogo tekhnologicheskogo universiteta - Bulletin of the Almaty Technological University, 6, 63-67 [in Russian].

16 Batyrbayeva, N.B., Zhiyenbayeva, S.T., \& Alimkulov, ZH.S. (2013). Analiz problemy obogashcheniya khlebopekarnoy muki biologicheski aktivnymi veshchestvami [Analysis of the problem of fortification of bread flour with biologically active substances]. Vestnik Almatinskogo tekhnologicheskogo universiteta - Bulletin of the Almaty Technological University, 5, 5-9 [in Russian].

17 Iztayev, A.I., Tursunbayeva, Sh.A, \& Magomedov, M.G. (2019). Innovatsionnyye tekhnologii proizvodstva khleba uskorennym sposobom s i bez ispol'zovaniya zakvaski i drozhzhey [Innovative technologies for the production of bread in an accelerated way with and without the use of sourdough and yeast]. Vestnik Almatinskogo tekhnologicheskogo universiteta - Bulletin of the Almaty Technological University, 1, 5-11 [in Russian].

18 Shansharova, D.A., Nurgozhina, Zh.K., Alashbayeva, L.Zh., \& Kaychibekova, G.M. (2019). Innovatsionnyye tekhnologii proizvodstva khleba uskorennym sposobom s i bez ispol'zovaniya zakvaski i drozhzhey [Innovative technologies for the production of bread in an accelerated way with and without the use of sourdough and yeast]. Vestnik Almatinskogo tekhnologicheskogo universiteta - Bulletin of the Almaty Technological University, 3, 5-8 [in Russian].

\author{
М. Б. Ребезов ${ }^{1}$, Е.Б. Никитин ${ }^{2}$, М.В. Темербаева ${ }^{2}$, Т.И. Урюмцева ${ }^{2}$ \\ «३В.М. Горбатов атындағы Федералды азық-түлік жүйелері ғылыми орталығы» \\ Федералды мемлекеттік бюджеттік ғылыми мекемесі, Ресей \\ ${ }^{2}$ Инновациялық Еуразия университеті, Қазақстан
}

\title{
Ресей мен Қазақстанда фортификацияланған тамақ өнімдерін өндірудің қазіргі жай-күйі мен перспективалары
}

Мақалада Қазақстан мен Ресейде фортификацияланған (байытылған) тамақ өнімдерін өндірудегі перспективалық бағыттар қарастырылады. Авторлар Ресей Федерациясы мен Қазақстан Республикасы аумағындағы фортификацияланған нан-тоқаш өнімдері өндірісінің қазіргі жай-күйіне талдамалық шолу 
жүргізді. Микроэлементтер жетіспеушілігіндегі ең көп таралған салдардың бірі - анемия екендігі сипатталған. Анемиямен байланысты мәселелер адамдардың денсаулығы мен әл-ауқаты үшін ауыр асқынуларға әкеледі. Диетадағы фолий қышқылы мен дәрумендердің жетіспеушілігі жүрек-қан тамырлары ауруларының, ана мен бала өлімінің себебі болып табылады.

Ұлт денсаулығына теріс әсер ететін өмір салтына, әдеттеріне немесе табыс деңгейіне қарамастан, Ресей мен Қазақстан халқының барлық топтарының тамақтануындағы елеулі ауытқулар туралы мәселе қарастырылады: орташа өмір сүру ұзақтығы қысқарады, еңбекке қабілетті халықтың өнімділігі мен ауруларға төзімділігі төмендейді.

Зерделенген отандық және шетелдік техникалық әдебиеттер, патенттік ақпарат негізінде Ресей Федерациясы мен Қазақстан Республикасында фортификацияланған тамақ өнімдерін өндірудің қазіргі жай-күйі мен перспективаларына талдамалық шолу жүргізілді.

Авторлар азық-түлікті фортификациялау - бұл тағамның қоректік сапасын жақсарту және адам денсаулығына жағымды әсер ету үшін азық-түліктегі витаминдер мен микроэлементтердің құрамын мақсатты түрде арттыру тәжірибесі екенін көрсетті. Авторлар қазіргі уақытта көптеген елдерде микронутриенттердің, оның ішінде Темірдің тапшылығы мәселесін жаппай тұтынылатын тамақ өнімдерін дәрумендер мен минералдармен байыту арқылы қалай тиімді шешуге болатындығы туралы мәселені қарастырды. Бидай ұнын темірмен фортификациялау процесі басқа микроэлементтермен және дәрумендермен бірге талқыланды, бұл темір тапшылығы анемиясы мен микронутриенттердің жетіспеушілігін болдырмауға арналған басқа стратегиялармен салыстырғанда бірқатар айқын артықшылықтарға ие. Премикспен фортификацияланған ұнды тұтынудың әдеттегі деңгейінде витаминдер мен микроэлементтерге орташа тәуліктік қажеттіліктің 30-50 \%-ын қанағаттандырады. Фортификация ұнның органолептикалық және басқа да қасиеттеріне әсер етпейді және жанама әсерлер тудырмайды. Осы проблема бойынша материалды зерттеу барысында маңызды аспект тек жоғары және бірінші сұрыпты ұн байытуға жататындығы анықталды, оны дайындау кезінде астық микронутриенттердің (дәрумендердің) ең көп мөлшері бар қабықтан тазартылады, байытылған ұнның сақтау мерзімі алты айды құрайды. Авторлар Ресей мен Қазақстанда осы проблеманы шешудегі ұтымды жолдарының бірі - халықтың барлық топтары үшін күнделікті және жаппай сұраныстың байытылған өнімдерінің ассортиментін кеңейту және технологияларын әзірлеу болып табылады деген қорытынды жасады.

Түйін сөздер: фортификация, микроэлементтер, витаминдер, премикс, фолий қышқылы, нантоқаш өнімдері, темір тапшылығы анемиясы.

\author{
М.Б. Ребезов ${ }^{1}$, Е.Б. Никитин ${ }^{2}$, М.В. Темербаева ${ }^{2}$, Т.И. Урюмцева ${ }^{2}$ \\ ${ }^{1}$ Федеральное государственное бюджетное научное учреждение \\ «Федеральный научный центр пищевых систем им. В.М. Горбатова», Россия \\ ${ }^{2}$ Инновационный Евразийский университет, Казахстан
}

\title{
Современное состояние и перспективы производства фортифицированных пищевых продуктов в России и Казахстане
}

В статье рассматриваются перспективные направления в производстве фотифицированной (обогащенной) пищевой продукции в Казахстане и России. Авторами проведен аналитический обзор современного состояния производства фортифицированных хлебобулочных изделий на территории Российской Федерации и Республики Казахстан. Описано, что одним из наиболее распространенных последствий дефицита микроэлементов является анемия. Проблемы, связанные с анемией, приводят к серьезным осложнениям для здоровья и благополучия людей. Недостаток фолиевой кислоты и витаминов в рационе является причиной сердечно-сосудистых заболеваний, материнской и детской смертности.

Рассмотрена проблема о существенных отклонениях в питании практически всех групп населения России и Казахстана, независимо от образа жизни, привычек или уровня дохода, которые крайне отрицательно сказывается на здоровье нации: сокращается средняя продолжительность жизни, снижается производительность трудоспособного населения и устойчивость к заболеваниям.

На основании изученной отечественной и зарубежной технической литературы, патентной информации проведен аналитический обзор современного состояния и перспектив производства фортифицированных пищевых продуктов в Российской Федерации и Республике Казахстан.

Авторами показано, что фортификация продуктов питания - это практика целенаправленного увеличения содержания витаминов и микроэлементов в продуктах питания для улучшения питательных качеств пищи и положительного эффекта для здоровья людей. Авторами рассмотрен вопрос о том, каким образом в настоящее время во многих странах эффективно решается проблема дефицита микронутриентов, в том числе железа, за счет обогащения витаминами и минералами продуктов питания массового потребления. Обсужден процесс фортификации пшеничной муки железом в комплексе с другими микроэлементами и витаминами, который имеет ряд очевидных преимуществ по сравнению с другими стратегиями по предотвращению железодефицитной анемии и дефицита микронутриентов. 
Фортифицированная премиксом мука удовлетворяет 30-50 \% средней суточной потребности в витаминах и микроэлементах при обычном уровне потребления муки. Фортификация совершено не влияет на органолептические и другие свойства муки и не вызывает побочных явлений. Также выявлено, что важным аспектом является то, что обогащению подлежит мука только высшего и первого сорта, при изготовлении которой зерно очищается от оболочки, содержащей максимальное количество микронутриентов (витаминов), срок хранения обогащенной муки составляет шесть месяцев. Авторами сделан вывод о том, что одним из рациональных путей решения данной проблемы в России и Казахстане является расширение ассортимента и разработка технологий обогащенных продуктов повседневного и массового спроса для всех групп населения.

Ключевые слова: фортификация, микроэлементы, витамины, премикс, фолиевая кислота, хлебобулочные изделия, железодефицитная анемия.

Date of receipt of the manuscript to the editor: 2020/10/29 